\title{
Evaluation of Literacy Programmes Delivery in Ogun State Nigeria
}

\author{
Soyele, H. A. ${ }^{1^{*}} \quad$ Egunyomi, D. ${ }^{2}$ \\ 1.Department of Adult and Non-Formal Education, Federal College of Education, \\ Osiele, Abeokuta, Ogun State,Nigeria \\ 2.Department of Adult Education, University of Ibadan, Oyo State, Nigeria
}

\begin{abstract}
In Nigeria, in order to care for the needs of some adults in the society, government have been able to put in place a number of programmes that will enhance Literacy education in Nigeria. Research studies in this area have dealt with curricula issues and implementation processes, which showed that the programme is making progress. In Ogun State however, there seem to be chronic inadequacy of resources, equipment, personnel and funds for implementation of Literacy Programmes Delivery as noted by the Ogun Annual Report.This study was carried out to evaluate literacy programmes delivery in Ogun State, Nigeria. The research design adopted for the study was a descriptive survey design. The population of this study was made up of Adult literacy facilitators and adult learners. Multi-stage sampling procedure was adopted to select two hundred and fifty participants. Response was sought from the respondents using structure questionnaires tagged 'Literacy Programme Delivery Questionnaire (LPDQ)' was used for data collection. Data collected were analyzed using frequency counts and percentages and Pearson Product Moment Correlation. The result shows that $72.8 \%$ of the respondents applied for post literacy programme; $69.1 \%$ of the literacy delivery center in the location used are government owned. It was also revealed in the result that Abeokuta-South has the highest number of facilitators this was followed by ObafemiOwode Local Government Area. On the accessibility of the programmes to people, $46 \%$ of the respondents reported that to a very great extent the programme has addressed their needs also $55.2 \%$ stated that to a great extent the schedule of activities for each term/session are well planned by management. It was also revealed in the study that $24.4 \%$ of the clienteles of the literacy programmes were traders and $13.6 \%$ fashion designers. On the adequacy of facilities, $40.8 \%$ of the respondents indicated that to a great extent plans are made for distribution of instructional materials, $48.8 \%$ also stated that classroom blocks are built for the programmes to a very great extent. On the availability of the instructional material; $53.2 \%$ of the respondents indicated to a great extent the availability of writing materials, $44.8 \%$ indicated adequate apparatus.Based on this, it can be concluded that more reinforcements should be infused into literacy programmes to motivate the adult learners to keep coming to the class. The facilitator should try to know the goals of the adult learners and find ways of achieving them during the programme. There should be awareness programme set up by both the government and non-governmental organizations on all available mass media in the state for people to be educated on literacy and for them to know the literacy centers they can go to for enrollment.
\end{abstract}

Keywords: Literacy Programmes, Adult learners, Adult Education

DOI: $10.7176 / \mathrm{JEP} / 11-4-02$

Publication date: February $29^{\text {th }} 2020$

\section{Introduction}

Education, which is officially perceived as an instrument "par excellence" for effecting National development is also an instrument for stability and change in any progressive society (Federal Republic of Nigeria 2004). According to the National Policy on Education and in line with the philosophy and goals of education in Nigeria, education fosters the worth and development of individuals and society in general. It is geared towards selfrealization, better human relationship, individual and national efficiency, effective citizenship, national consciousness, national unity, social, cultural, economic, political, scientific and technological progress. Ameh (2005) described education as a corner stone for development, that is, the basis for acquiring literacy, vocational skills, technological advancement and the ability to harness the natural resources of the environment. A National Literacy Survey (2010) conducted by the National Bureau of Statistics in Nigeria estimates the adult literacy rate as 56.9 percent, with huge variations between states (Lagos $92.0 \%$ and Bornu only $14.5 \%$ ), regions (urban $74.6 \%$ and rural $48.7 \%$,) and sex (male $65.1 \%$ and female $48.6 \%$ ). More importantly, statistics from the Federal Ministry of Education indicate that only 500,000 of the 40 million adult illiterates are enrolled in adult learning classes. There are also 3.5 million nomadic school-aged children with only 450,000 of them accessing any form of schooling. Nigeria is further saddled with the largest number of out-of-school-children estimated at over 7 million (10 percent of the global total).

Past researches have shown that illiteracy among people is a major challenge which could debar them from making progress in their life pursuit. Education and social values in Nigeria have deteriorated to the extent that adult learners' do not have the required impetus to see the need to acquire knowledge due to effect of lack of 
literacy programme which could affect their livelihood. Thus, it has affected greatly the educational sector of the country than any other sector. For some decade now, the issues on literacy programme have been a debate among the policy makers, researchers, government, and Non-governmental Organization, the School administrator and the school managers.

However, literacy programme is considered by many educators as a laudable programme. The programme is basically designed to provide reading and writing as well as vocational skills for adults and young people who miss the opportunity of formal education in their formative years. Over the years, researchers in education worldwide have focused research activities on issue around Literacy education, identifying ways and means of assessing it for its improvement because of its importance in National development.

Research studies in this area have dealt with curricula issues and implementation processes, which showed that the programme is making progress. In Ogun State however, there seem to be chronic inadequacy of resources, equipment, personnel and funds for implementation of Literacy Programmes Delivery as noted by the Ogun Annual Report from Mass Literacy Board 1995.The report, coupled with the increasing number of dropouts loitering the streets in rural areas, available few research studies in the area of evaluation of the management of the programmes in the state and the need to find ways of improving the programmes in the state necessitated this study. Therefore, this current study seeks to evaluate the extent to which the Literacy Programme Delivery impacted the society.

This current study is important from both the theoretical and practical view. The data generated from this study would serve as reference materials to other researchers in education, who may wish to carryout research in the area of Literacy Programme Delivery. It could create awareness to the stakeholders at the national level on the extent to which the management of the programmes at the state level are performing their functions thereby creating room for them to give closer supervision and provide more for the needs of the state. The National Mass Education Commission would use the empirical data realized from the study in organizing seminars, workshops or conferences for the stake holders and instructors of the programmes. Also the students of the programmes would benefit from the improvement of the programmes resulting from its evaluation and subsequent recommendations as more instructional and infrastructural facilities would be provided to enhance the understanding of their lessons. In addition more members of the society would be recruited thereby leading to reduction of unemployment in the state if the recommendations on the need for more facilitators are implemented. Equally, the manpower produced by the programmes would be useful to the society.

\section{Objective of the Study}

The main purpose of this study is to evaluate the Literacy programme delivery in Ogun State. Specifically, the study seeks to:-

i. Examine the kind of Literacy Programmes that are available in Ogun State.

ii. Examine those that are involved in Literacy Programme delivery in Ogun State.

iii. Determine how accessible the programme are to the people in Ogun State

iv. Examine the clienteles of the Literacy Programmes in Ogun State.

v. Determine how adequate the facilities are in Literacy Programmes Delivery in Ogun State.

\section{Methodology}

\section{Research Design}

The research design that was adopted for this study was the descriptive survey design of the ex-post facto type. It is a design in which a group of people, items or objects is studied by collecting and analyzing data from only a few people, items or objects considered to the exact representative of the entire group. This survey design method was used to find out the opinion of people in a given location toward an issue, item or event that may be of interest to the public in that geographical area being studied. Usually a cross section of people is sampled to whom questionnaire are administered. The results obtained from these are generalized to the population.

\section{Population of the Study}

The population for the study consisted of adult learners and facilitators who partook in literacy programmes in Ogun State. The above categories of respondents were used because they were the most likely group to know the extent to which the Literacy programmes Delivery is thriving being part of the system.

\section{Sample and Sampling Technique}

The sample size for this study consisted of 250 respondents that were drawn from five randomly selected Local Government Area of Ogun State using a multi stage sampling technique. The first stage involved the use of simple random sampling technique of Fishbowl with replacement to draw out ten (10) study centers in Ogun State. At the second sampling stage, five urban and rural study centers selected from the selected using simple random sampling technique of Fishbowl with replacement. At the third sampling stage, total enumeration was 
used to select respondents in all the arms of the centers at the urban and rural selected from which five respondents were drawn to make a total of 50 respondents for each study centre. Furthermore, a total of twenty (20) facilitators were randomly selected from the study area used.

\section{Instruments for Data Collection}

The instrument used for data collection in the study was a questionnaire. The instrument called Evaluation of Literacy Programmes Delivery Questionnaire (LPDQ) was used to elicit responses from the respondents. The first part of the instrument consisted of introductory letter to respondents stating the purpose of the study and an earnest request for the respondents to complete the items of the questionnaire. It also consisted of a request for personal data which sought the name of administrative unit of the respondents and rank/post. The second part of the instrument consisted of Sixty two (62) questionnaire items in five clusters meant to elicit written responses from the respondents. Cluster A contained information on the extent to which the Delivery of Literacy programmes plan for the achievement of the programme's objectives, cluster B contained information on the extent to which literacy programme is accessible to people, Cluster $\mathrm{C}$ has information on the extent to which the instructional material is available to people partaking in literacy programmes in Ogun State, Nigeria, Cluster D contains information on facilities of literacy programmes available at the Centre, while Cluster E contains information on facilitators of literacy programmes.

\section{Validation of Instrument}

In order to ensure the validity of the three instruments used for data collection, the draft of the instruments were face-validated by five experts - three in educational management and two others in measurement and evaluation Department of the University. The experts examined the relevance of the items to the research questions designed to guide the study, appropriateness and clarity of the statements and the weighting of the responses. Their corrections, comments and suggestions were used to modify the instruments.

\section{Reliability of the Instrument}

In order to ascertain the reliability of the instrument designed for this study, Cronbach Alpha method was used to determine the internal consistency reliability of the items. The use of Cronbach Alpha method was ensured by the fact that the items were not dichotomously scored. The internal consistency reliability coefficient obtained for each of the clusters A,B,C,D and E were $0.54,0.55,0.70,0.88$ and 0.56 respectively. The result for the whole set of scores was 0.61 . This showed that the instruments were highly reliable.

\section{Method of Data Collection}

Direct delivery technique was used for the administration of the Questionnaire. The researcher delivered the questionnaire in centers. In each of the centre, two weeks were allotted for the respondents to complete the questionnaire. Returning of the questionnaire was not completed until after three weeks because some of the respondents could not be seen at some times of visit by the researcher and the research assistants.

\section{Method of Data Analysis}

Mean was employed in analyzing the research data. The data collected using the nine research questions were analyzed using mean.

\section{RESULTS AND DISCUSSION}

Table 1: Showing distribution of Organizations involved in literacy delivery in Ogun state

\begin{tabular}{|l|l|l|}
\hline Organization & Frequency & Percent (\%) \\
\hline Government owned & 47 & 69.1 \\
\hline Non-Governmental Organizations & 21 & 30.9 \\
\hline Total & 68 & 100.0 \\
\hline
\end{tabular}

The table shows that $47(69.1 \%)$ of the literacy delivery center were owned by government while $21(30.9 \%)$ of the literacy center were owned by non-governmental organization. This implies that majority of the literacy delivery centers were owned by government.

Table 2: Showing literacy programme being offered in Ogun State

\begin{tabular}{|c|c|c|}
\hline & Frequency & Percent (\%) \\
\hline Basic Literacy & 65 & 26.0 \\
\hline Post Literacy & 182 & 72.8 \\
\hline Total & 247 & 98.8 \\
\hline Missing System & 3 & 1.2 \\
\hline Total & 250 & 100.0 \\
\hline
\end{tabular}


The table reveals that $65(26 \%)$ of the respondents indicated basic literacy as the literacy programmes available in Ogun State, while $182(72.8 \%)$ were having post literacy as their literacy programmes. This implies that majority of the respondents that participated in this study were having post literacy.

The findings from the study revealed that there are varieties of literacy programmes available in Ogun State but the most dominant was post literacy programmes. This finding corroborates that of Momoh (1995) who found that there is a steady increase in the number of adult learners who enrolled for post literacy in Nigeria. This shows that the finding of the study is in line with the recommendation of UNESCO (2006) that literacy should be meant for empowerment and national development. With the increase on the number of adult literate programmes and participants, it is evident that the Ogun State is moving towards achieving the goal of education for all.

Table 3: Distribution of the delivery process

\begin{tabular}{|l|l|l|}
\hline & Frequency & Percent (\%) \\
\hline Monday & 9 & 32.1 \\
\hline Tuesday & 3 & 10.7 \\
\hline Wednesday & 8 & 28.6 \\
\hline Thursday & 3 & 10.7 \\
\hline Friday & 5 & 17.9 \\
\hline Total & 28 & 100.0 \\
\hline
\end{tabular}

The table shows the delivery per day of literacy programme as revealed by the agencies involved. It can be inferred from the table that $9(32.1 \%)$ of the literacy centers had their programme on Monday between the hours of $4 \mathrm{pm}-6 \mathrm{pm}, 11 \mathrm{am}-2 \mathrm{pm}$ and $3 \mathrm{pm}-5 \mathrm{pm}$ in some other centers, also $3(10.7 \%)$ indicated their time on Tuesday between $1 \mathrm{pm}-4 \mathrm{pm}$ for some vocational center, $8(28.6 \%)$ had theirs on Wednesday usually between the hours of $4 \mathrm{pm}-6 \mathrm{pm}, 11 \mathrm{am}-2 \mathrm{pm}$ and $3 \mathrm{pm}-6 \mathrm{pm}$. Also 3 (10.7) indicated they had theirs on Thursday between the hours of $1 \mathrm{pm}-4 \mathrm{pm}$ and $4 \mathrm{pm}-6 \mathrm{pm}$ in the Local Government visited, furthermore, 5 (17.9\%) also revealed that they had their programme on Friday between $11 \mathrm{am}-2 \mathrm{pm}, 3 \mathrm{pm}-5 \mathrm{pm}$ and $4 \mathrm{pm}-6 \mathrm{pm}$. This implies that majority of the literacy centers delivered the literacy programme in the evening. In addition to the above information, they meet three (3) times in a week.

Table 4: Distribution of those involved in literacy delivery programme

\begin{tabular}{|l|l|l|l|l|}
\hline & Name of local & Center & Number & Percent \\
\hline 1 & Abeokuta North & Arinola Community Hall, Shoyeye & 1 & 5.0 \\
& & N.U.D. Primary School, Ilugun-Ikija, Abeokuta & 1 & 5.0 \\
\hline 2 & \multirow{2}{*}{ Ado-Odo-Ota } & L.G. SchIII,Igbala, Sango Ota & 1 & 5.0 \\
& & AUD comprehensive college (Vocational Center) Ota & 1 & 5.0 \\
\hline 3 & \multirow{2}{*}{ Obafemi-Owode } & O.O.LG Adigbe Abeokuta & 1 & 5.0 \\
& & St. David Anglican School, Ofada & 1 & 5.0 \\
& & All Saints' Primary School II Owode & 1 & 5.0 \\
& & Redemption Camp Mowe & 4 & 20.0 \\
\hline 4 & Abeokuta South & Baptist Church, Ibara, Abeokuta & 1 & 5.0 \\
\cline { 3 - 5 } & & The Redeemed Christian Church of God Directorate of & 6 & 30.0 \\
\hline 5 & Odeda & Olumo Primary School, Kugba-Ajagbe, Odeda & 2 & 10.0 \\
\hline & & OLG Primary School, Ilupeju, Agbaakin Bode-Olude & & 100.0 \\
\hline
\end{tabular}

The table shows the distribution of the facilitators by their local government of origin. It can be inferred that 1 of the respondents representing 5\% were from Abeokuta North (Arinola Community Hall, Shoyeye and N.U.D. Primary School, Ilugun-Ikija, Abeokuta), Abeokuta South (L.G. Sch III, Igbala, Sango Ota and A.U.D. comprehensive college (Vocational Center) Ota, Obafemi-Owode (O.O.LG Adigbe Abeokuta, St. David Anglican School, Ofada and All Saints' Primary School II, Owode) respectively. Also revealed from the study, 1 of the respondent representing 5\% is from Abeokuta South at Baptist Church, Ibara, Abeokuta. Furthermore, 4 of the respondents from Obafemi-Owode representing 20\% indicated Redemption Camp Mowe as their center, 6 (30\%) were from Abeokuta South also from The Redeemed Christian Church of God Directorate of Christian Education. In addition, 2 (10\%) were from Odeda Local Government Area with their center as (Olumo Primary School, Kugba-Ajagbe, Odeda and OLG Primary School, Ilupeju, Agbaakin Bode-Olude). It can be inferred from the result that large number of the facilitators was from The Redeemed Christian Church of God Directorate of Christian Education center reason being that it was funded by the Local Government as well as the Church members. 
Table 5: Showing the accessibility of the literacy programmes to the people

\begin{tabular}{|c|c|c|c|c|c|c|c|}
\hline $\mathrm{S} / \mathrm{N}$ & ITEM & VGE & GE & LE & VLE & Mean & Std.Dev. \\
\hline 1 & $\begin{array}{l}\text { There are awareness programme that are } \\
\text { put in place for people to be informed } \\
\text { about the existence of literacy programme }\end{array}$ & $\begin{array}{l}83 \\
(33.2 \%)\end{array}$ & $\begin{array}{l}115 \\
(46 \%)\end{array}$ & $\begin{array}{l}14 \\
(5.6 \%)\end{array}$ & $\begin{array}{l}38 \\
(15.2 \%)\end{array}$ & 2.97 & .999 \\
\hline 2 & The programme has addressed my needs & $\begin{array}{l}115 \\
(46 \%)\end{array}$ & $\begin{array}{l}124 \\
(49.6 \%)\end{array}$ & & $\begin{array}{l}11 \\
(4.4 \%)\end{array}$ & 3.37 & .707 \\
\hline 3 & $\begin{array}{l}\text { The schedule of activities for each } \\
\text { term/session are well planned by } \\
\text { Management }\end{array}$ & $\begin{array}{l}76 \\
(30.4 \%)\end{array}$ & $\begin{array}{l}138 \\
(55.2 \%)\end{array}$ & & $\begin{array}{l}36 \\
(14.4 \%)\end{array}$ & 3.02 & .939 \\
\hline 4 & $\begin{array}{l}\text { There are numbers of learning centers that } \\
\text { encourages learners to come for learning }\end{array}$ & $\begin{array}{l}105 \\
(42 \%)\end{array}$ & $\begin{array}{l}97 \\
(38.8 \%)\end{array}$ & $\begin{array}{l}40 \\
(16 \%)\end{array}$ & $\begin{array}{l}8 \\
(3.2 \%) \\
\end{array}$ & 3.19 & .819 \\
\hline 5 & $\begin{array}{l}\text { The learning center is very close to my } \\
\text { house }\end{array}$ & $\begin{array}{l}104 \\
(41.6 \%)\end{array}$ & $\begin{array}{l}68 \\
(27.2 \%)\end{array}$ & $\begin{array}{l}42 \\
(16.8 \%)\end{array}$ & $\begin{array}{l}36 \\
(14.4 \%)\end{array}$ & 2.96 & 1.07 \\
\hline 6 & $\begin{array}{l}\text { I can easily access the materials for the } \\
\text { programme }\end{array}$ & $\begin{array}{l}132 \\
(52.8 \%)\end{array}$ & $\begin{array}{l}110 \\
(44 \%) \\
\end{array}$ & & $\begin{array}{l}8 \\
(3.2 \%)\end{array}$ & 3.46 & .665 \\
\hline 7 & $\begin{array}{l}\text { The learning environment is conducive for } \\
\text { learning }\end{array}$ & $\begin{array}{l}91 \\
(36.4 \%)\end{array}$ & $\begin{array}{l}151 \\
(60.4 \%)\end{array}$ & & $\begin{array}{l}8 \\
(3.2 \%) \\
\end{array}$ & 3.30 & .635 \\
\hline 8. & $\begin{array}{l}\text { There is a balance between work and } \\
\text { school life }\end{array}$ & $\begin{array}{l}91 \\
(36.4 \%)\end{array}$ & $\begin{array}{l}81 \\
(32.4 \%)\end{array}$ & $\begin{array}{l}41 \\
(16.4 \%)\end{array}$ & $\begin{array}{l}37 \\
(14.8 \%)\end{array}$ & 2.90 & 1.60 \\
\hline 9. & $\begin{array}{l}\text { Learning tasks are relevant, meaningful, } \\
\text { interesting and useful }\end{array}$ & $\begin{array}{l}121 \\
(48.4 \%)\end{array}$ & $\begin{array}{l}50 \\
(20 \%) \\
\end{array}$ & $\begin{array}{l}27 \\
(10.8 \%)\end{array}$ & $\begin{array}{l}52 \\
(20.8 \%) \\
\end{array}$ & 2.96 & 1.19 \\
\hline 10. & $\begin{array}{l}\text { Each learner are been catered for according } \\
\text { to their abilities }\end{array}$ & $\begin{array}{l}83 \\
(33.2 \%)\end{array}$ & $\begin{array}{l}97 \\
(38.8 \%)\end{array}$ & $\begin{array}{l}26 \\
(10.4 \%)\end{array}$ & $\begin{array}{l}44 \\
(17.6 \%)\end{array}$ & 2.87 & 1.06 \\
\hline 11. & $\begin{array}{l}\text { Have been able to use the knowledge } \\
\text { gained in the programme to solve problems } \\
\text { in my day to day activities }\end{array}$ & $\begin{array}{l}84 \\
(33.6 \%)\end{array}$ & $\begin{array}{l}96 \\
(38.4 \%)\end{array}$ & $\begin{array}{l}26 \\
(10.4 \%)\end{array}$ & $\begin{array}{l}44 \\
(17.6 \%)\end{array}$ & 2.88 & 1.06 \\
\hline 12. & $\begin{array}{l}\text { Learners are involved in planning of the } \\
\text { time table }\end{array}$ & $\begin{array}{l}70 \\
(28 \%)\end{array}$ & $\begin{array}{l}86 \\
(34.4 \%) \\
\end{array}$ & $\begin{array}{l}50 \\
(20 \%)\end{array}$ & $\begin{array}{l}44 \\
(17.6 \%)\end{array}$ & 2.72 & 1.05 \\
\hline & \multicolumn{5}{|l|}{ Weighted mean } & 3.05 & \\
\hline
\end{tabular}

Please note that VGE $=$ Very Great Extent, GE $=$ Great Extent, LE $=$ Little Extent, VLE $=$ Very Little Extent

The table shows that $115(46 \%)$ of the respondents indicated to a great extent there are awareness programme that are put in place for people to be informed about the existence of literacy programme, on the same note $124(49.6 \%)$ indicated that to a great extent the programme has addressed their needs. Furthermore, $138(55.2 \%)$ indicated that to a great extent the schedule of activities for each term/session are well planned by the management. However $105(42 \%)$ indicated to a very great extent there are numbers of learning centers that encourages learners to come for learning, $104(41.6 \%)$ indicated to a very great extent the learning centre they choose is very close to their houses.

Furthermore, $132(52.8 \%)$ stated that to a very great extent they can easily access the materials for the programme. The learning environment was conducive as revealed by $151(60.4 \%)$ of the respondents that the learning centre used to a great extent is very conducive for learning, $91(36.4 \%)$ also indicated that to a very great extent there is balance between work and school life. Also $121(48.4 \%)$ revealed that the learning tasks are relevant, meaningful, interesting and useful to a very great extent. While $97(38.8 \%)$ indicated that each learner are been catered for according to their abilities to a great extent.

Conclusively, $96(38.4 \%)$ of the respondents indicated to a great extent they have been able to use the knowledge gained in the programme to solve problems in their day to day activities, on the same note, 86 (34.4\%) indicated to a great extent learners are involved in planning of the timetable.

Considering the information gathered from the table, it can be seen that the means for the accessibility programme to learners' rise above the criterion mean of 2.50 set for perception of learners' view on the accessibility of literacy programmes. Also, the grand mean of 3.05 is greater than the criterion mean of 2.50 which is set for high accessibility of the programme by adult learners'. This implies that adult learners in Ogun State have access to literacy programme in Ogun State.

The finding from this study reveals that there is an increase in the accessibility of literacy programmes at the designated venues for literacy programmes. Access to education is an important concern to nations all over the world. In Nigeria, it is observed that many sections of the population have no access to literacy education or the life skills necessary for their economic and social well-being (NFE policy guidelines 2012). The policy guideline went further to state that with such worrisome situation, the Nigerian Government has realized that 
unless aggressive measures are taken to scale up literacy, the Education for All (EFA) goals III and IV relating to learning and life-skills for all young people and 50\% reduction of youth and adult illiteracy by 2015 will not be achieved. This has made the Federal Ministry of Education to launch the revitalization of youth and adult literacy programmes in March 2011 in order to help increase the literacy rate and ultimately contribute towards the achievement of EFA and Millennium Development Goals as well as the national development goals of empowering the people on wealth creation and economic growth.

Table 6: Showing the clienteles who partake in literacy programmes

\begin{tabular}{|l|r|r|}
\hline Clientele & Frequency & \multicolumn{1}{c|}{$\begin{array}{c}\text { Percent } \\
\text { (\%) }\end{array}$} \\
\hline Barbers & 14 & 5.6 \\
\hline Carpenters & 5 & 2.0 \\
\hline Caterers & 12 & 4.8 \\
\hline Cleaners & 1 & .4 \\
\hline Drivers & 10 & 4.0 \\
\hline Electricians & 6 & 2.4 \\
\hline Farmers & 1 & .4 \\
\hline Fashion Designers & 34 & 13.6 \\
\hline Guards & 11 & 4.4 \\
\hline Nursery school Teachers & 13 & 5.2 \\
\hline Painters & 12 & 4.8 \\
\hline Plumbers & 5 & 2.0 \\
\hline Politicians & 13 & 5.2 \\
\hline Radio repairers & 15 & 6.0 \\
\hline Taxi drivers & 1 & .4 \\
\hline Teachers & 10 & 4.0 \\
\hline Traders & 61 & 24.4 \\
\hline Welders & 26 & 10.4 \\
\hline Total & 250 & 100.0 \\
\hline
\end{tabular}

The table shows that 14 of the respondents representing $5.6 \%$ were barbers, $5(2 \%)$ practiced carpentry work, $12(4.8 \%)$ were caterers, $1(0.4 \%)$ cleaner, farming and taxi driving respectively. Also, $10(4 \%)$ were driver and teaching respectively. The table shows further that $6(2.4 \%)$ of the respondents were electricians, 34 $(13.6 \%)$ were fashion stylists, $11(4.4 \%)$ were guards, $12(5.2 \%)$ were nursery school teachers, $12(4.8 \%)$ were painters, $5(2 \%)$ were plumbers, $13(5.2 \%)$ were politicians, $15(6 \%)$ were radionics, $61(24.4 \%)$ were traders and $26(10.4 \%)$ were welders. This implies that majority of people that benefits from this literacy programme were traders.

The result reveals that majority of the participants of this study were artisans such as trading, stylist among others who are willing to improve their literacy level and enhance their skills. Education plays an important role in development. Out-of-school programmes, in particular, are central to providing adaptable learning opportunities, and new skills and knowledge to, a large percentage of people outside the reach of formal education (Vermaak, 1985). Non-formal education today should be seen as related to the concepts of recurrent and lifelong learning. Fordham (1993) suggests four characteristics associated with non-formal education: Relevance to the needs of disadvantaged groups; concern with specific categories of person; a focus on clearly defined purposes; and flexibility in organization and methods. In addition to what has already been mention about non-formal education and national progress, it should be noted that adult literacy is particularly relevant to development and to reducing gender inequality. Adult literacy increases women's participation in both private and public activities, i.e. in house hold decision-making and as active citizens in community affairs and national development. Adult literacy programmes have a dramatic impact on women's self-esteem because they unleash their potential in economic, social, cultural and political spheres. According to the UNESCO (2010), non-formal education in particular helps to: ensure equal access to education, eradicate illiteracy among women, and improve women's access to vocational training, science, technology, and continuing education. It also encourages the development of non-discriminatory education and training, allocates sufficient resources for and monitors the implementation of educational reforms, and promotes women's and girl's life-long education and training. 
Table 7: Showing the adequacy of the facilities in the literacy centers

\begin{tabular}{|c|c|c|c|c|c|c|c|}
\hline $\mathrm{S} / \mathrm{N}$ & Items & VGE & GE & LE & VLE & Mean & $\begin{array}{l}\text { Std. } \\
\text { Dev. }\end{array}$ \\
\hline 1. & $\begin{array}{l}\text { Plans are made for distribution of } \\
\text { instructional materials }\end{array}$ & $\begin{array}{l}55 \\
(22 \%)\end{array}$ & $\begin{array}{l}102 \\
(40.8 \%)\end{array}$ & $\begin{array}{l}20 \\
(8 \%)\end{array}$ & $\begin{array}{l}73 \\
(29.2 \%) \\
\end{array}$ & 2.55 & 1.13 \\
\hline 2. & $\begin{array}{l}\begin{array}{l}\text { Classroom blocks built for the } \\
\text { programmes }\end{array} \\
\end{array}$ & $\begin{array}{l}122 \\
(48.8 \%)\end{array}$ & $\begin{array}{l}87 \\
(34.8 \%)\end{array}$ & & $\begin{array}{l}41 \\
(16.4 \%)\end{array}$ & 3.16 & 1.05 \\
\hline 3. & $\begin{array}{l}\text { Classrooms for the programmes in } \\
\text { conventional secondary schools }\end{array}$ & & & $\begin{array}{l}122 \\
(48.8 \%)\end{array}$ & $\begin{array}{l}128 \\
(51.2 \%)\end{array}$ & 1.49 & .501 \\
\hline 4. & $\begin{array}{l}\text { Classrooms for the programmes within } \\
\text { the community-town halls, village } \\
\text { squares, etc. }\end{array}$ & $\begin{array}{l}133 \\
(53.2 \%)\end{array}$ & $\begin{array}{l}15 \\
(6 \%)\end{array}$ & $\begin{array}{l}102 \\
(40.8 \%)\end{array}$ & - & 3.12 & .963 \\
\hline 5. & Seats in the classrooms & $\begin{array}{l}122 \\
(48.8 \%)\end{array}$ & $\begin{array}{l}128 \\
(51.2 \%)\end{array}$ & - & - & 3.49 & .501 \\
\hline 6. & Office accommodation for staff & $\begin{array}{l}15 \\
(6 \%) \\
\end{array}$ & - & $\begin{array}{l}108 \\
(43.2 \%) \\
\end{array}$ & $\begin{array}{l}127 \\
(50.8 \%)\end{array}$ & 1.61 & .775 \\
\hline 7. & Viewing centers for learners & - & $\begin{array}{l}29 \\
(11.6 \%)\end{array}$ & $\begin{array}{l}64 \\
(25.6 \%) \\
\end{array}$ & $\begin{array}{l}157 \\
(62.8 \%)\end{array}$ & 1.49 & .696 \\
\hline 8. & $\begin{array}{l}\text { Vehicles to convey learners for } \\
\text { excursions }\end{array}$ & - & $\begin{array}{l}45 \\
(18 \%)\end{array}$ & $\begin{array}{l}63 \\
(25.2 \%)\end{array}$ & $\begin{array}{l}142 \\
(56.8 \%)\end{array}$ & 1.61 & .775 \\
\hline 9. & Vehicles for sensitization/campaign tours & - & $\begin{array}{l}14 \\
(5.6 \%)\end{array}$ & $\begin{array}{l}94 \\
(37.6 \%)\end{array}$ & $\begin{array}{l}142 \\
(56.8 \%)\end{array}$ & 1.49 & .603 \\
\hline 10. & Electricity & - & - & $\begin{array}{l}108 \\
(43.2 \%)\end{array}$ & $\begin{array}{l}142 \\
(56.8 \%)\end{array}$ & 1.43 & .496 \\
\hline 11. & Boreholes & & $\begin{array}{l}15 \\
(6 \%) \\
\end{array}$ & $\begin{array}{l}107 \\
(42.8 \%) \\
\end{array}$ & $\begin{array}{l}128 \\
(51.2 \%)\end{array}$ & 1.54 & .607 \\
\hline 12. & Toilets & $\begin{array}{l}88 \\
(35.2 \%)\end{array}$ & $\begin{array}{l}72 \\
(28.8 \%)\end{array}$ & $\begin{array}{l}50 \\
(20 \%) \\
\end{array}$ & $\begin{array}{l}40 \\
(16 \%) \\
\end{array}$ & 2.83 & 1.08 \\
\hline & \multicolumn{5}{|l|}{ Weighted mean } & 2.02 & \\
\hline
\end{tabular}

Please note that VGE $=$ Very Great Extent, GE $=$ Great Extent, LE $=$ Little Extent, VLE $=$ Very Little Extent

The table shows that $102(40.8 \%)$ reveals that to a great extent plans are made for distribution of instructional materials, $122(48.8 \%)$ indicated to a very great extent, classroom blocks built for the programmes, $133(53.2 \%)$ also asserts that to a very great extent classrooms for the programmes within the community-town halls, village squares, etc. Also, 128 (51.2\%) revealed that to a great extent there are seats in the classrooms.

However, $128(51.2 \%)$ states that to a very little extent classrooms for the programmes are in conventional secondary schools. Also,127(50.8\%) revealed that to a very little extent there is availability of office for staff, $157(62.8 \%)$ also states that to a very little extent most learning centers have a viewing centers for learners. Furthermore, $142(56.8 \%)$ state that to a very little extent, there are vehicles to convey students for excursions and vehicles for sensitization/campaign tours respectively. On the same note $142(56.8 \%)$ revealed that to a very little extent there is electricity in the learning centre, $128(51.2 \%)$ also reported to a very little extent there is availability of boreholes in their learning centre while $88(35.2 \%)$ states that to a very great extent there are availability of toilets in their learning centers.

Considering the information gathered from the table, it can be seen that the means for the adequacy of facilities to learners' rise above the criterion mean of 2.50 set for perception of learners' view on the adequacy of facilities for literacy programme. Also, the grand mean of 2.02 is lower than the criterion mean of 2.50 which is set for adequate facilities set for the literacy programme for adult learners'. This implies that adult learners in Ogun State lack adequate facilities for literacy programme.

The result of this study shows that the facilities are in adequate as expected by most of the participants of the study. Physical resources are instructional and curriculum materials employed in classes or teaching learning experiences. The availability and utilization of resources are predictors to the successful implementation of any academic programme. According to Offorma (2002) teaching is usually facilitated and is more effective through the active participation of the learners and utilization of appropriate resources. Active participation of the learner in physical education is facilitated by the availability and effective utilization of adequate instructional resources personnel, facilities, equipment and supplies.

Akande (2005) noted that teaching and learning are better and easier done through one's interaction with one's environment. Environment here refers to facilities and equipment utilized in teaching physical education. Similarly, Egwu (2005) noted that it is obvious that teacher competency and available instructional facilities and equipment in a school determine the coverage of syllabus and curriculum of any subject. According to Ikioya 
(2008) the center programme requires the availability and adequacy of facilities, equipment and supplies for the attainment of set goals. School resources have been observed as a potent factor to quantitative and qualitative education (Owoeye 2011). Resources according to Hornby (2004) are what can be used to help achieve an aim such as equipment and facilities which provide information for the teachers and students. Nikky (2010) referred to teaching resources as the different equipment available in the classroom, adding that the process of teachinglearning depends upon the different types of equipment available in the teaching environment. Teaching resources are therefore all the facilities, equipment and supplies utilized by the teacher in teaching the subject. Nikky, (2010) summarized the following as some of the importance of teaching resources in teaching. Teaching resources help the teacher present concepts in a way that the learners can retain more concepts permanently; it helps the teacher to motivate the students, by making the environment more interesting to the students. Teaching resources facilitate proper understanding by the adult learner and discourage the act of cramming, it also makes the classroom or learning environment lively and active.

\section{Summary}

This research work investigated on Literacy programmes delivery in Ogun State, Nigeria. The study consists of five chapters with the first chapter discussing extensively the background to the study. This consists of background to the study, statement of the problem, purpose of the study, significance of the study, scope of the study, research questions and the operational definition of terms. Chapter two focused on the review of related literature to the study. This consists of theoretical framework, review of related concept and review of relevant Studies. Chapter three of the study centers on the methodology used in carrying out the research work. Chapter four discussed in details analysis results and discussion of the findings. While chapter five closes with the summary, conclusion, recommendations and suggestions for further studies.

\section{Conclusion}

In conclusion, the study establishes that, there are both government owned and Non Governmental organization study centers in Ogun State, with majority been owned and controlled by the government. Majority of the respondents that participated in this study had post literacy programme. Also, adult learners in Ogun State have a positive perception towards the literacy programme and adult learners in Ogun State have access to literacy programme in Ogun State. Likewise majority of people those benefits from this literacy programme were traders while it also reveals that adult learners in Ogun State lack adequate facilities for literacy programme. It was also revealed that, adult learners in Ogun State do not have enough instructional materials for literacy programme. Lastly, adult learners in Ogun State have positive view of their facilitators as being adequate and competent for literacy programme.

\section{Recommendations}

The following recommendations are given based on the outcomes of this study:

(i) During the course of the study, it was observed that it is basic and post literacy that are majorly offered in the state, government should make provision for well equipped vocational (skill acquisition) centers for people that might prefer acquiring a skill or two to sitting in evening classes.

(ii) More reinforcements should be infused into literacy programmes to motivate the adult learners to keep coming to the class.

(iii) The facilitator should try to know the goals of the adult learners and find ways of achieving them during the programme.

(iv) There should be awareness programme set up by both the government and non-governmental organizations on all available mass media in the state for people to be educated on literacy and for them to know the literacy centers they can go to for enrollment.

(v) Sensitization should not only be in market areas but also in the communities and streets to enlighten other groups of people asides the traders.

(vi) During the course of the study, it was observed that the seats available in the classrooms were for pupils, government should provide seats that would be suitable and comfortable for the adult learners.

(vii) Arrangements should be made for adult learners to be taken on excursion once in a while for them to be exposed and for them to have a better understanding of what they have been taught in the centre.

(viii)Government should provide the centers with up to date and useful materials that will be used by both the facilitator and the adult learners in the learning process.

(ix) Adult learners should be encouraged by their facilitators to develop materials on their own that will help them better understand what they have been taught.

(x) During the course of the study, it was observed that the facilitators were not well remunerated, government should remunerate the facilitators more for them to be motivated to come to help the adult learners learn. 


\section{REFERENCES}

Akande, O.M. 2005. Hints on Teaching Practice and General Principle of Education. Lagos, OSKO Associates. Akpa, G.O. (2000). A critical appraisal of adult education delivery in Nigeria.

Ameh, H.J. 2005. Constraints to the administrative functions of Kogi State Teaching Service Commission unpublished M.Ed. thesis department of educational foundations, University of Nigeria, Nsukka.

Egwu, S.D. 2009. Principals' performance of instructional leadership functions in Ebonyi State secondary schools. An Unpublished Ph. D. Thesis, EBSU AbakaIiki.

Federal Ministry of Education, (2001). National mass education link (NMEC Link)

Fordham, P. E. 1993. Informal, non-formal and formal education programmes. In YMCA George Williams College ICE301 Lifelong Learning Unit 2, London: YMCA George Williams College.

National Teachers Institute (2010). A training Manual for Capacity Building of Teachers Under the Federal Teacher's Scheme (FTS): Basic Science Technology. Kaduna: National Teachers Institute.

NFE Policy Guideline (2012). Policy Guidelines for Adult and Non-formal Education in Nigeria. Abuja: National Commission for Mass Literacy.

Nikky, C.A. 2010, Teaching Aids, their needs, types and importance of teaching aids in teaching learning process.

Ofoegbu, T. O. 2009. Teaching and Learning Resources. In Curriculum Organization of Nigeria(Ed).Curriculum Theory \& Practice. (131-159). Abuja: Curriculum Organization of Nigeria.

Owoeye, J.S. 2011.School Facilities and Academic Achievement of Secondary School Agricultural Science in Ekiti State, Nigeria. Unpublished Ph.D. Thesis Kampala International University, Kampala, Uganda.

UNESCO 2006a.Guidebook for planning education in emergencies and reconstruction. Paris: UNESCO

UNESCO 2006b. Education For All Global Monitoring Report.

UNESCO 2010.Gender Equality, Education and Training. 